\title{
B. Sharon Byrd \& Joachim Hruschka, Kant's Doctrine of Right. A Commentary
}

\author{
Thomas Mertens
}

\section{B. Sharon Byrd \& Joachim Hruschka, Kant's Doctrine of Right. A Commentary (Cam- bridge: Cambridge University Press, 2010), 336 p.}

Het contrast kan nauwelijks groter zijn. Kants rechtsleer is een heel slecht boek, schrijft Schopenhauer in het begin van de 19de eeuw, dat van fouten aan elkaar hangt. En dat moet wel het gevolg zijn van het feit dat Kant op hoge leeftijd was toen hij dit boek schreef. Het boek zit inderdaad slecht in elkaar, schrijft Ludwig zo'n dertig jaar geleden, want er ging van alles fout in het proces dat van Kants originele handschrift leidde tot de gedrukte versie van de Metaphysik der Sitten. Daarom bezorgde Ludwig ons een nieuwe, overigens helemaal niet onomstreden, editie waarin diverse tekstgedeelten uit de rechtsleer in een andere volgorde werden geplaatst.

Niets van dat al, beweren Byrd en Hruschka aan het begin van de $21^{\text {ste }}$ eeuw. Kants rechtsleer is een nauwkeurig gestructureerd en geformuleerd meesterwerk uit de rechtsfilosofie en de politieke filosofie. Daarin wordt op een euclidische manier vanuit een zeer beperkt aantal assumpties een heel systeem van individuele rechten ontwikkeld. Vervolgens wordt aangegeven wat die rechten impliceren voor de inrichting van de statelijke, de interstatelijke en de kosmopolitische rechtsorde. Niemand voor of na Kant heeft op zo een radicale manier conclusies getrokken uit het feit dat de mens het aangeboren recht heeft op vrijheid om externe objecten in zijn bezit te hebben. Inderdaad heeft Kant het zijn lezers niet gemakkelijk gemaakt. Het was hem er primair om te doen om zijn theorie op orde te krijgen, niet om die theorie en de vaak zeer beknopte uitleg ervan op een toegankelijke wijze te presenteren.

Daarmee is het eerste uitgangspunt van dit commentaar gegeven. Volgens Byrd en Hruschka heeft Kant het in zijn rechtsleer bij het rechte eind en waar de tekst zichzelf lijkt tegen te spreken of ondoorgrondelijk en verwarrend lijkt te zijn, is dat niet het probleem van Kant, maar van diens lezers. De rechtsleer moet niet bekritiseerd worden, maar zodanig geïnterpreteerd worden dat de ideeën ervan een uniek, compleet en logisch consistent geheel vormen. Het tweede uitgangspunt is dat Kants eerdere teksten in de rechtsfilosofie en politieke filosofie, zoals Naar de eeuwige vrede en Over de gemeenplaats: dat kan in theorie wel juist zijn, maar deugt niet voor de praktijk (zojuist in een nieuwe, door mij en Eric Boot verzorgde, uitgave verschenen bij Boom uitgevers Amsterdam), van weinig betekenis zijn voor Kants uiteindelijke positie in de rechtsleer. Ten opzichte van die teksten heeft Kant zijn positie immers enerzijds grondig uitgebreid (met een traktaat over het privaatrecht) en anderzijds drastisch gewijzigd, zodat die eerdere teksten 
voor de interpretatie van de rechtsleer weinig betekenis hebben. Daarentegen is, ten derde, de invloed van Achenwalls natuurrecht op Kants benadering en vocabulaire in de rechtsleer zo groot dat (enkel) met behulp daarvan de moeilijkheden die men in eerste instantie in de rechtsleer denkt aan te treffen, kunnen worden opgehelderd. Ten slotte willen de auteurs niet of nauwelijks met de contemporaine secundaire literatuur over Kants rechtsleer in discussie gaan. In hun commentaar beroepen zij zich nagenoeg uitsluitend op auteurs uit Kants eigen omgeving omdat Kant met die teksten vertrouwd was en die dus behulpzaam zijn om de rechtsleer te begrijpen.

Het resultaat van deze aanpak is, ik kan het niet anders zeggen, verbluffend. $\mathrm{Na}$ de uitleg over deze uitgangspunten vinden we een strak gecomponeerd boek. Daarin wordt een reconstructie gepresenteerd van de hoofdlijn van Kants rechtsleer aan de hand van een analyse van Paragraaf 41, waarin Kant niet alleen de overgang maakt van het privaatrecht naar het 'openbaar recht', maar ook drie zogenaamde 'leges' introduceert (lex iusti, lex iuridica en lex iustititiae) die dan vervolgens met de drie essentiële instituties van de kantiaanse staat wordt verbonden: de wetgevende macht, de vrije markt en de rechtsprekende macht. Vervolgens komen aan de orde: de tegenstelling natuurtoestand - rechtstoestand; het recht op vrijheid; het juridisch postulaat van de praktische rede op grond waarvan eigendom mogelijk is; de diverse vormen van eigendom die Kant onderscheidt; de staat; de internationale en de kosmopolitische rechtsorde. De auteurs gaan bekende moeilijkheden niet uit de weg, zoals de betekenis van de vele Romeinsrechtelijke adagia die Kant gebruikt, waaronder de genoemde 'leges' en de drie regels van Ulpianus, van Kants (vaak mis verstane) stelling dat strafrecht een categorische imperatief is, en van de stelling dat het moreel behoren het kunnen (navolgen van dat behoren) impliceert. Dat leidt tot het beeld van een minimale staat die enkel draait om het veilig stellen van de natuurlijke rechten van mensen en om het garanderen van een vrije markt waarin mensen onder het motto volenti non fit uniuria volledig vrij zijn om eigendom te verhandelen. De staat wordt niet geacht in te grijpen in de privaatrechtelijke verhoudingen die zich als het ware in de natuurtoestand, dat wil zeggen zonder staatsbemoeienis, hebben ontwikkeld en mogen ontwikkelen. Op grond van Kants afwijzing van een paternalistische regering en van Cicero's stelling dat het welzijn van het volk de hoogste wet voor de staat is, concludeert dit commentaar dat Kant elke vorm van een welvaartsstaat afwijst. Deze vrijemarktinterpretatie van Kant beperkt zich vervolgens niet tot het niveau van de staat, maar leidt tot een pleidooi voor een kosmopolitische rechtsorde die in het teken staat van een vrije wereldhandel.

Dit commentaar is bijzonder nuttig voor degenen die al een grote vertrouwdheid hebben met Kants rechtsleer en die bereid zijn deze tekst te (her)lezen tezamen met dit commentaar. Het is zeker geen eenvoudige kennismaking met Kants rechtsleer. Hoe nuttig dit commentaar voor mij ook is, ik ben het om een variëteit van redenen regelmatig oneens met de interpretaties die Byrd en Hruschka hier op vaak apodictische wijze presenteren. Omdat mij hier de ruimte ontbreekt, volsta ik met een algemene aanduiding van enkele van mijn bezwaren. Ten aanzien 
van de relatie tussen de rechtsleer en de eerdere teksten van Kant over recht en politiek: hoe aannemelijk is het dat Kant tussen 1792 en 1795/6 enerzijds en 1797/8 anderzijds zijn inzichten over de inrichting van de staat, en met name over de internationale rechtsorde radicaal zou hebben veranderd? Een voorbeeld: volgens Byrd en Hruschka erkent Kant in de rechtsleer, in tegenstelling tot in Naar de eeuwige vrede, het recht op oorlog als een 'toegestaan middel' tegen een 'ongerechtvaardigde vijand'. In 'Kant en de traditie van de rechtvaardige oorlog' (Tijdschrift voor Filosofie 73 (2011), 467-88) betoog ik daar tegenin dat Kants opmerkingen in de rechtsleer begrepen moeten worden als een beschrijving van de natuurtoestand tussen staten, maar niet als de erkenning van een ius ad bellum dat hem niet alleen tot een representant van de traditie van de rechtvaardige oorlog zou maken, maar bovendien het vooruitzicht op een blijvende vrede zou vernietigen. Ook op Kants vermeende libertarisme kan wel wat worden afgedaan: het is veelbetekenend dat Allgemeine Anmerkung C bij Paragraaf 49, waarin Kant sociaaleconomische verplichtingen van de staat ten aanzien van onder andere armenzorg aan de orde stelt, in het commentaar niet besproken wordt. Meer in zijn algemeenheid kunnen voorzieningen ten behoeve van een zekere herverdeling door de staat inderdaad niet gerechtvaardigd worden met een beroep op paternalisme, dat Kant inderdaad afwijst, maar wel met een beroep op de bescherming van de burgerlijke zelfstandigheid, namelijk het recht om niet aan de willekeur van anderen overgeleverd te zijn, dat door Kant wordt onderschreven.

Ook op diverse andere onderdelen van de interpretatie van dit commentaar kan het nodige worden afgedaan. Ik sluit echter af met een algemene observatie. Kants Metaphysik der Sitten vormt een tweeluik, waarin we naast een rechtsleer ook een deugdenleer aantreffen. Over de eenheid van de Metaphysik der Sitten lezen we bij Byrd en Hruschka heel weinig. Zij beschouwen de rechtsleer als een op zich staand werk dat helemaal draait om 'individuele rechten'. Maar Kant heeft niet voor niets telkens de Metaphysik der Sitten (en niet een rechtsleer) aangekondigd en ten slotte als een eenheid gepubliceerd. Het becommentariëren van de rechtsleer als een geïsoleerd werk heeft dan ook grote gevolgen. Neem bijvoorbeeld de eerste regel van Ulpianus: honeste vive. Die regel komt inderdaad in de rechtsleer voor en wordt door Byrd en Hruschka opgevat als een beklemtoning van het feit dat eenieder een juridisch persoon met individuele rechten is. Echter, de plicht tot het leiden van een eerzaam leven kan natuurlijk zélf geen recht zijn. Het honeste vive is primair een plicht die iemand heeft ten opzichte van zichzelf. Daarom heeft Kant geaarzeld of de regels van Ulpianus in de rechtsleer dan wel in de deugdenleer geplaatst moesten worden; we vinden het 'eerzaam leven' dan ook in de deugdenleer terug. Met deze bezinning op de eerste regel van Ulpianus als een plicht (zoals in mijn Mens \& Mensenrechten, p. 445-9) verlaten we echter het perspectief van de rechtsleer als een protolibertair traktaat over individuele rechten en komt de eenheid van de Metaphysik der Sitten terug in beeld als een rijk en tamelijk klassiek geheel van plichten, rechten en deugden. 